\title{
'Glocalization' versus Notions of Decoupling: A Critical Appraisal of the Impact of Global Economics on National Economic Performance
}

\author{
MICHAEL JAKOBSEN
}

\begin{abstract}
Discussing modes of political and/or economic decoupling in an era of economic globalization seems almost contradictory as the dominating keywords in the latter are increasing integration, interdependency and harmonization. For example, when looking towards the political realm it seems problematic to suggest that a nation-state can opt for a withdrawal from the global community in order to nurture its domestic potential. Likewise, when looking towards the economic realm, it seems even more problematic to suggest the possibility of a national economy withdrawing from the global economy, taking an increasing internationalization of domestic markets into account. Nonetheless, there is a discourse devoted to just that, namely whether or not to decouple economically and politically from the global community. The present article explores this discourse by first taking a critical look at the concept of decoupling. It then proceeds by presenting a different approach towards the study of the relationship between the global and national level by introducing the notion of triangulation. It is argued that the relationship between economic globalization, national economics and a given societal context in which the two former are embedded, is governed by various layers of interdependency. This means that one cannot solely focus on one point in the triangle and thus decouple, so to speak, the other two in order to understand, for example, the political or economic forces at play there. According to the argument forwarded in this article, one has to take all three points in the triangle into account in order to disentangle and thus understand the complex web of interdependency among the three. To illustrate the workings of this approach, a case study of the ramifications of a newly initiated national economic development plan in Malaysia is introduced. The article ends by returning to the decoupling discourse to re-examine it in the light of the findings from the case study. ${ }^{1}$
\end{abstract}

Keywords: decoupling, triangulation, economic development, inter-ethnic relations, industrialization, nation building, Penang, Malaysia 


\section{Introduction}

When discussing the current global financial crisis, one of the striking features, besides the negative ramification for the global as well as for the individual national economy, is the externalization of the strong linkages between the different international financial markets as well as the individual national economy's lack of ability to shield its domestic market from the negative effects from the international crisis. This points towards a world community that does not consist of independent nation-states in a realist sense, but rather of nation-states that are bound together in a political and economic community characterized by interdependency and an ever-increasing process of political and economic integration. Despite these seemingly obvious facts, there is nonetheless a lively discourse on whether a national economy, or aspects of a national economy, can decouple, either completely or momentarily, from this global-cum-local state of interdependency. Interestingly, this discourse has been (re)fuelled by the current major difference between Western and Asian markets. As it is now (August 2011), the former are on the edge of moving into recession, whereas the latter are experiencing growth rates at around 5 to 7 per cent, not to mention China and India, with their current growth rates almost hitting double-digit figures, according to the Global Competitiveness Report 2010-2011. ${ }^{2}$ Does this difference between Western and Asian markets allow the latter to at least momentarily decouple from their troubled Western counterparts in order to nurture their developmental potential?

The present article explores the viability of this discourse by first taking a critical look at the discourse of decoupling. It then proceeds by presenting an alternative approach to studying the relationship between the global and national by introducing the concept of triangulation. It is argued that the relationship between economic globalization, national economics and a given societal context in which the first two are embedded, is governed by various layers of interdependency. This means that one cannot solely focus on one point in the triangle, thus decoupling, so to speak, the two other in order to understand, for example, the political forces at play there. One has to take all three points in the triangle into account to disentangle and thus understand the complex web of interdependencies among them. To illustrate the workings of this approach, a case study based on the newly initiated national development plan in Malaysia is introduced. The article ends by returning to the decoupling discourse to re-examine it in the light of the findings from the case study. 


\section{On the Notion of Decoupling: Real Possibility or an Intellectual Exercise?}

The intellectual roots behind the notion of decoupling can be found in the Dependency School, which dominated mainstream political and economic discourses during the 1960s, 1970s and 1980s with its focus on the world as divided into a so-called First World versus a Third World political and economic power structure. The theoretical foundation behind this bifocal view of the world was mainly based on neo-Marxist approaches formulated by scholars such as Frank (1978), Banaji (1977), Amin (1974), Emmanuel (1972) and Wallerstein (1979). The point of departure of this school of thought was the political and economic processes that had their origin in a colonial and imperialist past, which then manifested themselves in a global centre-periphery relationship in which the centre monopolized and controlled processes of capital accumulation that were fuelled by resource extraction in the periphery. ${ }^{3}$ These approaches were applied mainly to Latin America and Africa. The link to the discourse on decoupling was provided by Frank, who maintained that Third World countries should de-link from the First World in order to develop, as such linkages were harmful for the periphery. With fewer linkages to the centre, Third World countries could concentrate on domestic development and import substitution, all guided by a developmental state based on a revolutionary socialist ideology (Frank 1978).

This theoretical macro perspective was later replaced by theories of globalization in which multinational companies were the main players and nation-states acted as economic facilitators for domestic industrial internationalization processes, developments that in particular have been discussed within international business theory by Porter (1990), Dunning and Lundan (2009), Shenkar (2004) and Rugman and Verbeke (2004), just to mention a few scholars in this rich field of research. Up until 2008 observers found supportive evidence for budding notions of decoupling especially in Asian emerging markets. A good case in point is the discourse on 'Asian values' during the 1970s, 1980s and early 1990s (see for example, Jacobsen and Bruun 2000), and again after the Asian financial crisis in 1997 that showed tremendous economic growth rates especially in China and India and much higher growth rates in the rest of East and Southeast Asia compared to the Western economies. As such, Asian economies were perceived to be resistant to the contractions in the American and European economies due 
to their strong and constantly growing domestic markets, high currency reserves and prudent macroeconomic policies, partly based on experiences learnt during the 1997 financial crisis and partly based on perceived specific modes of doing business compared to their Western counterparts. ${ }^{4}$

During 2008 and 2009, however, cracks in the notion of decoupling began to emerge. The meltdown on Wall Street in 2008 sent shockwaves through the entire global financial system, not least in the Asian markets. Contrary to what those who believed in decoupling expected, the losses were even greater outside the US, with the worst experienced in emerging markets and developed economies such as Germany and Japan. ${ }^{5}$ Even though China was relatively hard hit by the global economic contraction that followed the financial meltdown, it managed to engineer a decent rebound (together with India and a group of larger emerging economies in Asia), whereas the US, Europe and Japan still remain more or less on the verge of recession.

In the first half of 2011 it seemed as if the global economy was approaching the second bottom of a seemingly 'W-shaped' (also called 'double dip') economic crisis. Taking into account the many fiscal stimulus packages introduced by states in 2009 and 2010 to stabilize national economies around the globe, it seems at least for the time being that the Asia packages have had the greatest impact on the individual economies, thus rejuvenating an otherwise rather battered discourse on regional or national modes of decoupling. However, the main question remains whether the current growth of the Asian economies is a sign of a budding decoupling from the global economy, and in particular from the Western economies. It is still too early to state this as a fact, as we do not know whether the current recovery will be sustained once the effects of the massive stimulus packages begin to fade.

Taking a critical approach towards analyzing these developments from a decoupling perspective is the relationship between decoupling and the underlying process of internationalization of individual national economies. Even though a given national economy has been stimulated and facilitated in its development by the state, this is not to say that the economy is also becoming detached from the global economy. The linkages between a national economy and the global economy are still very much in place, as can be seen when looking at the national economy's dependence on foreign direct investments (FDI) for its continued growth, and through its membership of the World Trade Organization (WTO), thus gradually aligning its modes of developing its own economy with 
the global one. ${ }^{6}$ Turning towards political decoupling, this has been tried by ASEAN through its developmental regionalism experiment initiated in 1998. That experience was closed down in 2001 due to heavy criticism by the major global economic players as an attempt to introduce differentiated levels of competitiveness between the national, regional and global levels, thus damaging the free flow of capital between them (Nesadureai 2004).

Thus, it is rather problematic to employ the notion of decoupling, as global and local linkages are rather strong and pervasive. It seems as if the discourse on decoupling is not aware of the current gradual dismantling of the historically conditioned Western economic hegemony, a condition that is being replaced by a more fluid, interdependent and contextualized economic world order that is based on shifting centres of capital accumulation. Asia is a very good case in point (and China and India in particular), taking the current developments in this region into consideration. Decoupling or recoupling, if we are to use these terms at all, seem to be not so much economic in nature, but rather constitute a part of a politically inspired discourse in which the notions of de- or re-coupling constitute a potent political signifier. Taking this stand on decoupling reduces it to a domestic policy manifestation that reflects a given position in an international landscape of multiple and shifting power centres, thereby unintentionally accepting an increasing global interdependency between and harmonization of individual national economies as discussed especially by Rugman and Verbeke (2004).

\section{Introducing a Different Approach to Notions of Decoupling}

Before introducing a different approach to analyzing the relationship between economic globalization and national economies, it is important to take a closer look at the current global political and economic landscape to identify the various opportunities and constraints that are impacting the different economies in the Asian region. Based on a geo-economic understanding of the global economy, Thomas L. Friedman, in his book, The World is Flat: A Brief History of the Twenty-First Century (2005), put forward the notion that the world is flat as a metaphor for viewing the world economy as an increasingly level playing field. This means that everybody in the global marketplace has an equal opportunity in terms of doing business. Due to what Friedman calls 'the ten flatteners', ${ }^{7}$ which all have led towards global interdependency, the so-called steroids, ${ }^{8}$ 
combined with the triple global convergence, ${ }^{9}$ as well as modes of doing business in the global marketplace, have gradually become more aligned, especially in the beginning of the twenty-first century.

These global developments have had a strong impact on regional and local differences, integrating them and thus hybridizing them to such an extent that the regional and the local cannot be distinguished as separate entities but only as integrated parts of the overall global economic whole. The ultimate consequence of what can thus be called 'a glocalized marketplace' is the development of an ever-increasing market fragmentation with implications for both global and local levels of competition, network practices and forms of company ownership. Due to time-space compression, as discussed by Harvey (1989), inter- and intra-firm communication is thus instantaneous, making adaptation to local market and institutional conditions an option and not a necessity!

The Nobel Prize-winning economist Joseph Stiglitz has been rather critical of Friedman's notion of a flat world. In his book Making Globalization Work, he writes:

Friedman is right that there have been dramatic changes in the global economy, in the global landscape; in some directions, the world is much flatter than it has ever been, with those in various parts of the world being more connected than they have ever been, but the world is not flat [...] Not only is the world not flat: in many ways it has been getting less flat (Stiglitz 2006: 7).

In another reaction to the notion of a flat world, Richard Florida (2005) from George Mason University argued that the world is not flat but 'spiky'. According to Florida, the world can be divided into three separate major categories that together make up the modern economic landscape: cities that generate innovations, economic 'hills', and the 'valleys' in between the two former. To illustrate this, he and some colleagues developed a map that shows geo-economically what a 'spiky world' would look like. The map illustrates economic activity estimated on the basis of light emission. Many cities, despite their large populations, barely register due to low levels of economic activity.

The cities that are capable of generating technological innovations constitute the tallest peaks on this map and are difficult to topple. They attract global talent and create new products and industries. The so-called 'economic hills' are places that manufacture the world's established goods and support innovation engines. The hills can rise and fall quickly; they are prosperous but insecure in terms of investment. Finally, there are the 'valleys' in between the other two categories. These 
are places or areas with little connection to the global economy and thus few immediate prospects for economic development.

According to this geo-economic perspective, the world is definitely not flat but constitutes a highly differentiated but interdependent landscape, if we are to believe these categorizations. In order to further substantiate the notion of a spiky world there are, however, more advanced ways of showing that a differentiated, interdependent and indeed 'spiky' economic landscape is rather close to reality. One of these ways can be found in international business theory (Peng and Meyer 2011; Peng 2009; Ahlstrom and Bruton 2010). Besides showing that the various national economies are indeed interrelated and interdependent, theoretical approaches from this school of thought delineate various types of markets that are a direct reflection of the current forces that define the structure of the global economy.

\section{What Makes a Landscape 'Spiky' and not Flat?}

To answer this question one has to divide the global market into three main types: developed markets, transitional and/or emerging markets and bottom of the pyramid (BOP) markets. The so-called developed markets are those that contain the highest 'spikes'. These types of markets can generally be found in what can be termed high-trust societies. This refers to societies in which a high level of trust is placed in governmental institutions that provide for accountability, checks and balances, judicial protection, and punishment of official corruption. In other words, these markets are defined by rules and regulations and as such attract a vast number of international and domestic investors. ${ }^{10}$ Furthermore, the societies in which these markets can be found can be characterized as exhibiting moderate growth rates and having stable political regimes.

The role of the state in developed markets can be organized into two main ideal types: liberal market economies (LMEs) and coordinated market economies (CMEs). ${ }^{11}$ In short, the role of the state in the LMEs can be characterized as minimal. This means that the state plays a minor role in regulating the market and ideally leaves the market to its own regulatory mechanisms with only minor interventions in order to stimulate the economy. In this category one would place, for example, the US and UK markets. This perception of the US and UK markets has temporarily changed due to the impact of the current financial crisis. The state has to a great extent increased its intervention into those two markets so as 
to facilitate an otherwise faltering economy. There are, however, heavy political costs associated with this new practice. This can be seen especially in the US, where Republican politicians are heavily attacking the Obama administration for being almost socialist in its approach towards the current crisis thus more or less leading to a stalemate within the political establishment. The role of the state in a CME can be categorized as Keynesian. Here the state plays a major role as an economic facilitator and regulator, a role that expands and contracts according to fluctuations in the market. This kind of market can be found mainly in Germany and Scandinavia. Both of these two major ideal types of economic markets are within the developed market category. ${ }^{12}$

Turning towards transitional and/or emerging markets, this is where one finds the 'hills'. They can generally be characterized as going through a period of transition from a planned economy towards an open market economy (as, for example, Russia, China and Vietnam are currently doing), and based on more or less functioning formal rules and regulations due to the impact from localized mindsets and traditional value systems. Other characteristics are high growth rates, very competitive low-cost manufacturing, high-risk economies and unstable political regimes. In general, the kind of societies one finds in these kinds of markets can be defined as low-trust societies. This means that individuals do not trust official institutions due to corruption and non-transparent political and bureaucratic practices leading to inefficient implementation of the rules and regulations emanating from the formal institutions. Instead they turn to informal networks based on family relations and non-kin-centred network practices built on relational trust between, for example, business partners. ${ }^{13}$ In other words, informal institutions have a rather greater impact on the functionality of the formal institutions, thus creating what Peng and Zhou (2005) have termed 'institutional voids'.

In terms of market characteristics, a transitional and/or emerging market can be positioned somewhere between an LME and a CME. This means that the role and involvement of the state in the economy is relatively high. There is a host of literature on the state in these kinds of markets referring to the state as being either an interventionist state or a developmental state that to a great extent is involved in the economy and thus also in the overall national industrial development (see for example Hutchinson 2009 and Beh 2007). Although variations of the developmental type of state can also be found in developed markets, it is mainly related to transitional and/or emerging markets, where market structures are relatively weak and unregulated and thus easy prey 
for global competition. These kinds of markets can be found in former Eastern Europe and Russia, Latin America, Africa, India and most of Asia except Japan, South Korea, Taiwan, Hong Kong and Singapore.

The final category of markets I will touch upon in this context is the so-called 'bottom of the pyramid' also called 'BOP' markets. They constitute the 'valleys' according to Richard Florida's typology. They can be characterized by an absence of formal institutions, that is, of very few or no formal rules and regulations at all. Here informal rules can be understood as mainly socially sanctioned norms of behaviour that are embedded in cultural and religious practices as well as in local value systems. BOP markets are characterized by people who live in rural areas and urban slums and shanty towns. They have few assets, have little or no education, are outside conventional distribution, credit and communication networks, and they subsist on less than US $\$ 4$ a day (Peng 2009:

6) These types of markets are scattered throughout the world, mostly in countries outside the West, for example, in parts of Latin America, Africa, India, China and Southeast Asia. One of the interesting things about BOP markets is that they have the potential to develop into emerging markets should the government invest in infrastructure thus preparing the ground for companies other than multinational corporations (MNCs) to tap into these markets. The main companies behind this kind of development are often successful pioneers who first established themselves in these difficult markets. One such pioneer is Unilever Hindustan, which operates rather successfully in an Indian BOP market. ${ }^{14}$

\section{Background and Main Features of an Emerging Market: The Case of Asia}

There are several features that act as drivers in the Asian markets. Perhaps one of the most important ones is a liberalization of markets, which includes deregulation and privatization as well as a reduction of trade and investment barriers. Many of these initiatives are prompted in part by economic globalization and in part by state-initiated economic development schemes in which incoming FDI constitutes an important prerequisite. Interestingly, most East and Southeast Asian countries did not subscribe to import substitution programmes in the 1960s and 1970s as most of the Latin American countries did. This had something to do with the geopolitical positions of the two regions vis-à-vis the US. For example, the industrialization of South Korea and the other so-called 'Asian tigers' was in line with the US's geopolitical strategy of build- 
ing a 'contention belt' of capitalist countries around China and other communist states in Asia, which involved granting incentives for these countries to export to the US. In contrast, Latin American countries were outside the main areas of US geopolitical concerns in this connection, as the US saw them as constituting its own backyard.

In short, what is an import substitution policy? Originally it was a strategically designed national politically initiated trade and economic programme that was directed toward the domestic market. It was especially prevalent in the 1970s as part of the developmental schemes of several states, especially in Latin America. It generally worked by having the state nationalize and/or subsidize key industries as well as develop high entry barriers for foreign capital in the form of, for example, tax schemes so as to protect domestic industries against international competition. One of the positive things that can be mentioned in this context is that it created employment, thus strengthening the political legitimacy of the state. In this sense it was thus more of a policy scheme than an economic development plan. Eventually import substitution programmes were abolished, as the domestic markets were generally too small to maintain or even build up a sustainably high level of GDP. Basically, there were too few people buying locally produced products in the domestic market. Finally, and perhaps more importantly, the policy failed because countries could not de-link themselves from other countries, as they depended too much on foreign capital, especially foreign direct investments, as well as access to international markets for their products in order to increase local capital accumulation (Krugman and Obstfeld 2009).

Instead, an aggressive market liberalization took place, especially after the Asian financial crisis in 1997. This resulted in increased jockeying for FDI among the different countries, thus furthering the differences between the countries in the region due to their growing individual industrial capabilities. This occurred despite the fact that they were becoming increasingly more interdependent due to the construction of several regional organizations such as ASEAN+1, ASEAN+3, AFTA, etc. These increasingly more complex developments have resulted in an asymmetrical ranking between the different Asian economies, as the development path of the individual country is strongly dependent on its specific resources, institutions, economic structure and political ideologies, not forgetting the specificity of the individual local, social and cultural fabric (Evans 2005; Campbell 2005). This increasing complexity and interdependency among the countries within ASEAN as well as among the East Asian countries raises a critique of the notion 
of 'best practice' in, for example, international business theory. Based on the above, the main question is whether it is at all possible to talk about a 'best practice' in an emerging market, taking all its complexities and volatility into account. The same goes for whether it is possible for individual nation-states to decouple from these developments. Just as in the case of the notion of best practice, the answer has to be 'no', based on the above discussion of the interdependent and yet different types of markets found in the Asian region.

\section{Zooming Further in on the Asian Markets: The Case of Malaysia}

As discussed above, the Asian markets and their relations to the global economy do indeed constitute a landscape from which it is very difficult to decouple. Furthermore, it is a dynamic economic and political landscape that consists of a few 'spikes' such as Japan, South Korea, Taiwan, Hong Kong and Singapore, just to mention the most prominent, several 'hills', including Malaysia, Indonesia, Thailand, the Philippines and Vietnam, and some 'valleys': Cambodia, Laos and Burma. Interestingly, the states in the last group are rather stable in terms of their categorization, but the 'hills' are vigorously jockeying to become the highest 'hill' in the region in terms of economic performance, thus making the markets in this part of the world quite volatile. In this section we shall zoom in on Malaysia, a country that has for some time been termed one of the most politically stable and economically dynamic 'hills' in Southeast Asia, in order to assess its potential for decoupling in case it finds a need for doing so, politically, economically or otherwise.

The Malaysian market economy can be classified as being in the upper end of the Southeast Asian emerging markets. According to the Economist Intelligence Unit's May 2011 report on Malaysia, ${ }^{15}$ it forecasts Malaysia's political stability during the period 2011-2015 to come under moderate threat, not because of any major shift in the balance of power, but rather owing to internal strife within the two main political alliances. The Economist Intelligence Unit expects the governing Barisan Nasional (BN) coalition to call an early election, most likely in 2012, a year before its current term ends. Fiscal policy will be tightened gradually during the forecast period, as the government strives to balance its budget by 2020. Monetary policy will also become tighter as domestic demand strengthens. The economy is expected to resume a fairly stable growth path during the period following a mild recession in 2009 and a strong 
rebound in 2010. Real GDP growth will average 5.4 per cent per year in the forecast period. The rate of inflation will accelerate to 3.2 per cent in 2011 and will then average 3.6 per cent a year in 2012-2015. The government plans to rationalize the country's extensive subsidy schemes, and this will push up consumer prices. Despite the faster pace of growth in merchandise imports than in exports, Malaysia will continue to post substantial trade and current-account surpluses in the forecast period.

\section{Malaysia - A Declining 'Hill'?}

Taking these macroeconomic and policy predictions at face value, Malaysia can apparently be defined as a fairly stable and sound 'hill'. This goes in particular for Penang, one of the dynamic 'sub-hills' in the Malaysian economic landscape, due to its heavy focus on manufacturing and innovation in various high-tech industry sectors, especially in the electrical and electronic sector (Araffin 2011). However, there is another side to this story. Zooming further in on Penang the picture becomes more complex. Poh Heem Heem, from the both publicly and privately funded Penang Skills Development Center (PSDC), agrees that economically speaking, Malaysia is ahead of most of its ASEAN competitors, mainly in the export of commodities and in the electronic components sector. However, according to Poh the rate of this progress has slowed down, which she attributes to Malaysia being caught in the so-called 'middle income trap' (Poh 2010: 46). As a kind of response to the figures and predictions put forward in the 2011 Economist Intelligence Unit's report, she characterizes the Malaysian economy as exhibiting more problematic developments including an erosion of its competitive base, a decrease in private investments, and a decline in productivity and a serious 'brain drain' within both academia and industry (Yeah 2011).

Poh's advice to the national government (2010: 46) is that Malaysia must boost the value-added dimension of its exports if it is not to lose its status as a strong growth-oriented economy. In addition, one of the defining features of the 'middle income trap' is a lack of industrial innovation. During fieldwork in Penang in March 2011, the author discussed this issue with several informants from within the automation industry. The main issues were whether there was a lack of innovative capability or lack of an innovative environment in Penang. The informants believe that there are many talented and innovative people in Penang. This was also stressed by researchers from the Socio-Economic and Environmental Research Institute (SERI), one of the main Penang think-tanks, who also 
stressed a need for industrial innovation. They saw a lack of innovation as due to, in part, complacency on behalf of the current entrepreneurs and/or in part due to the current full employment situation, which, according to the informants, in itself does not encourage innovative thinking. This, along with the high cost of developing completely new products, results mainly in industries further developing already existing products, rather than developing new ones. According to the informants, this is not what industrial innovation is all about, as it does not help the industry or Penang for that matter, to move up the value chain. Only new products have the capacity to do that. It is important to mention here that this view of the importance of innovation is fully supported by the Global Competitiveness Report covering the period 2009-2010. ${ }^{16}$

\section{A Malaysian Federal Government Response to this State of Affairs}

Both the Malaysian federal government and the Penang state government are well aware of the difference in outlook between the predictions for growth as formulated in the Economist Intelligence Unit's May 2011 report and the more critical insights that domestic researchers air about the state of the Malaysian economy and the Penang state economy in particular. To counter the critical voices the federal government has designed what it calls a 'New Economic Model' (NEM), a plan to operationalize one of the 'four pillars' to facilitate a process of national economic change, namely the Economic Transformation Programme (ETP) ${ }^{17}$ The NEM consists of a series of strategic reform initiatives proposed by the National Economic Advisory Council to put the ETP into action.

As can be seen in Table 1, the NEM approach is liberal in its orientation towards the market in order to further open it up to foreign as well as domestic investors.

There is an emphasis on economic growth led by the private sector, a localized decision-making process and a favouring of technologically capable industries and firms, thus providing the background to further attract foreign direct investment (FDI). Gone are centralized strategic planning, state participation in the economy and restrictions on foreign skilled workers. The shadow from the developmental state that lies over the 'old approach' appears to have disappeared. The recommendations from the 'new approach' in the NEM fit very well into the current developmental tendencies in the global economy, where trade liberalization and open markets are the dominant issues on the agenda. The main 
TABLE 1: New and Old Economic Approach

\begin{tabular}{|l|l|}
\hline Old Approach & New Approach \\
\hline $\begin{array}{l}\text { Growth through capital accumulation } \\
\text { Dominant state participation in the economy } \\
\text { (CME) }\end{array}$ & $\begin{array}{l}\text { Growth through productivity } \\
\text { Pentralized strategic planning }\end{array}$ \\
Balanced regional growth & $\begin{array}{l}\text { Localized autonomy in decision-making } \\
\text { Cluster- and corridor-based economic activi- } \\
\text { ties }\end{array}$ \\
Favour specific industries and firms & $\begin{array}{l}\text { Favour technologically capable industries and } \\
\text { firms }\end{array}$ \\
Export dependence on G-3 markets & Asian and Middle-Eastern orientation \\
Restrictions on foreign skilled workers & Retain and attract skilled professionals \\
\hline
\end{tabular}

tenet in the NEM is a deeper engagement in the global economy thus promoting a higher degree of interdependency with the global economy. Due to this 'open door' economic policy, it becomes harder for the Malaysian state to employ a political and/or economic approach based on decoupling from its global engagement in case it wants to nurture more domestic developmental schemes and interests.

Figure 1 shows how the NEM will go about operationalizing the strategic reform initiatives. The basic premise is that vested interests have created a logjam that is blocking transformation and growth and that the Malaysian people must be prepared for the upcoming changes.

Eight strategic reform initiatives have been developed to transform the economy in such a way that together they would lead toward higher growth. This will result in a constructive triangulation of high income, economic sustainability and social and political inclusiveness, resulting in improved quality of life. The checks and balances in this system are feedback mechanisms, which should lead to a review and an eventual revision of the whole developmental process, thus insuring a maximum positive impact on the Malaysian economy and ultimately the Malaysian society.

\section{Introducing a Triangulation Approach to Assess the Viability of the NEM in a 'Glocalized' Context}

As mentioned in the beginning of this article, one of the main themes to be developed here is a model of economic triangulation to delineate an increasing interdependency between global and local markets, thus demonstrating the problems behind the argument that it is possible to decouple national economic initiatives from the global economy. Before going into detail, however, it is important to provide a background for 
FIGURE 1: The New Economic Model: Enablers and Strategic Reform Initiatives

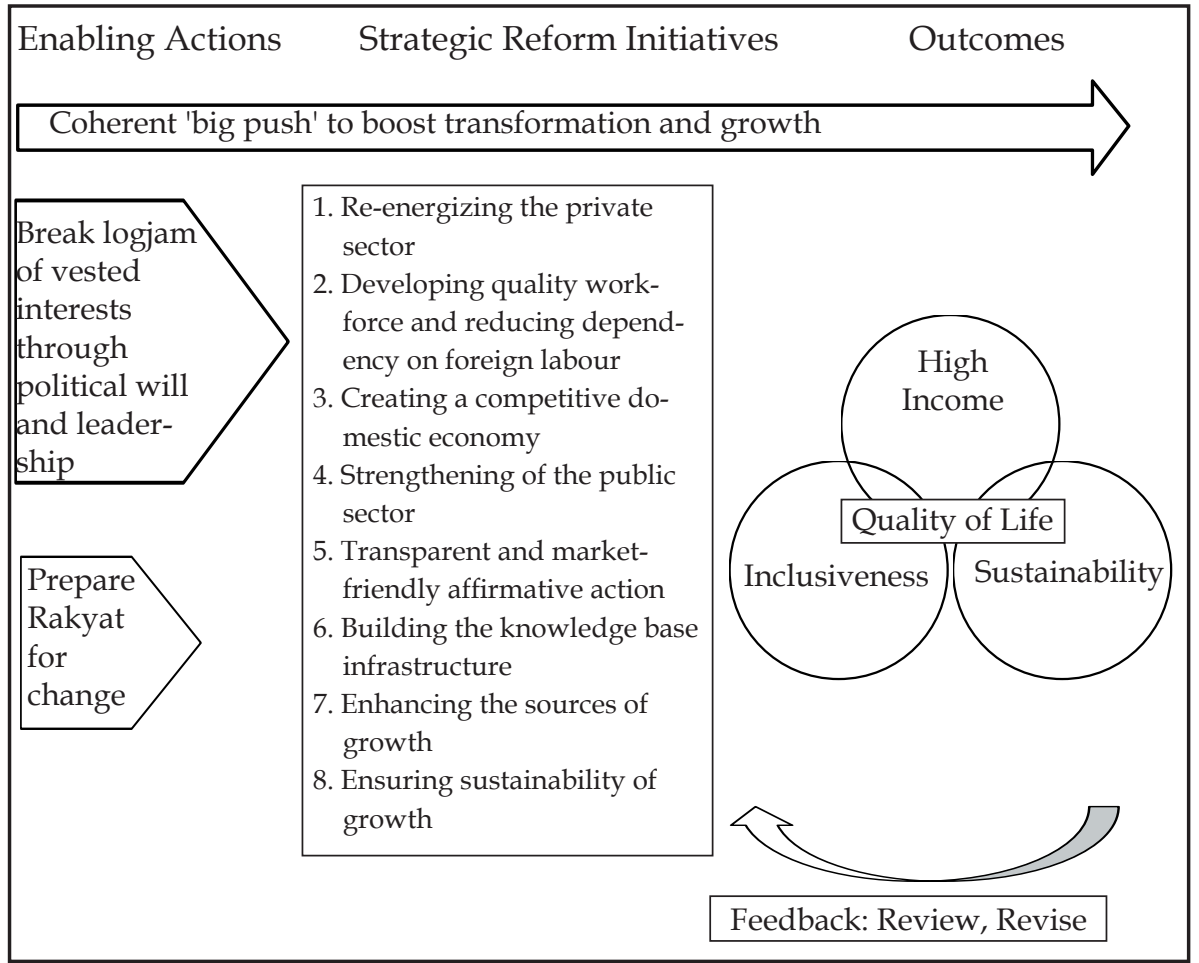

Source: Penang Economic Monthly, June 2010: 49.

selecting Malaysia as a case study for this analysis, as opposed to other nations within Southeast Asia. Using the figures from the Global Competitiveness Report 2010-2011, ${ }^{18}$ I have selected four Southeast Asian countries besides Malaysia to position the Malaysian economy in a Southeast Asian context. Singapore has been left out of the equation as it is economically speaking far above the other Southeast Asian countries and should be related to countries such as Hong Kong, South Korea and Taiwan. Furthermore, Laos and Burma are not included in the report due to a lack of data. The four selected countries are Indonesia, Thailand, Vietnam and Cambodia. The reason for including Cambodia is to show the span between the selected countries. Malaysia and the four selected countries are measured in terms of: competitiveness, basic requirements, ${ }^{19}$ efficient enhancers, ${ }^{20}$ and innovation and sophistication factors.

Malaysia leads in all four categories. However, Thailand and Indonesia are not that far behind, and Vietnam, at least in terms of competitiveness, is on its way to catching up with the other Southeast Asian countries, thus becoming a serious player in the near future. Nonetheless, 
TABLE 2: Ranking of Selected Southeast Asian Nations According to the Global Competitiveness Report 2010-11

\begin{tabular}{|l|c|c|c|c|c|}
\hline & \multicolumn{2}{|c|}{$\begin{array}{c}\text { Competitiveness } \\
\text { 2009-2010 }\end{array}$} & $\begin{array}{c}\text { Basic } \\
\text { requirements }\end{array}$ & $\begin{array}{c}\text { Efficient } \\
\text { enhancers }\end{array}$ & $\begin{array}{c}\text { Innovation \& so- } \\
\text { phistication factors }\end{array}$ \\
\hline Malaysia & 24 & $26^{\text {a }}$ & 33 & 24 & 25 \\
\hline Indonesia & 54 & 44 & 60 & 51 & 37 \\
\hline Thailand & 36 & 38 & 48 & 39 & 49 \\
\hline Vietnam & 75 & 59 & 74 & 57 & 53 \\
\hline Cambodia & 110 & 109 & 113 & 103 & 106 \\
\hline
\end{tabular}

Source: Global Competitiveness Report 2010-2011.

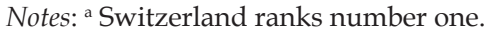

due to the fact that Malaysia tops the list of Southeast Asian countries (again disregarding Singapore), this country fits nicely into the following analysis, as it constitutes a benchmark for measuring the other countries in terms of regional competitiveness.

Returning to the discussion of economic triangulation, I will in the following apply a triangular approach to analyze the Malaysian market in a global economic context. The focal points in the triangle consist of (1) how foreign investors 'read' the Malaysian market, (2) domestic societal factors, and finally (3) the impact of the national economic policy in this context.

In order to 'read' and thus prepare a company for entering a foreign market, in this case the Malaysian one, Dunning and Lundan (2009) suggest that foreign investors could take a theoretical point of departure in the Elective Paradigm, also termed the OLI paradigm, and combine that with Barney's (1991) Resource Based View (RBV). When employing the three analytical levels of the OLI paradigm, namely (O) ownership specific advantages, (L) location specific advantages and (I) internalization specific advantages, as a theoretical approach for entering the Malaysian market combined with the RBV in order to update, reinforce and maintain a company's level of competitiveness, and combining this with the macro-economic figures as outlined in the Economist Intelligence Unit's 2011report plus key economic figures provided by the Malaysian national economic statistical bureau, a green light for investing in this market is given. In other words, positive macroeconomic figures encourage foreign investors to invest despite the fact that some domestic researchers from PSDC and SERI point toward the problematic state of affairs in terms of a flagging level of FDI, a small increase in domestic productivity and a decrease in international competitiveness. However, as we have seen, the federal and state governments are already addressing these critical challenges through the NEM strategy aided in a specific 
Penang context by economic facilitators such as Penang Development Center, investPenang and PSDC.

Turning towards the second point of the triangle, which deals with societal factors, foreign investors might combine the OLI and RBV with an institutional theoretical approach as developed by North (1991), Scott (2008) and Peng (2002). Here the emphasis is not on key economic figures but rather on Malaysian society's institutions as well as how the two main categories of societal institutions, formal institutions (consisting of more or less well defined and enforced rules and regulations in relation to the juridical system, industrial and political development schemes, educational as well as social welfare systems, etc.) and informal institutions (religion, culturally defined value systems, collectivist and family-oriented social systems, etc.), relate and impact each other.

Having defined the Malaysian market as belonging to the emerging market category, Peng (2002) states that in general, informal institutions have a rather great impact on the functionality, implementation and applicability of the formal institutions thus making the overall society more or less unstable. If one was to employ institutional theory on the Malaysian market, the perspective, as seen by an international investor, would not be as bright as when looking at it through the key economic figures. The problems excavated through this theoretical lens consist of a rather severe brain and capital drain, ${ }^{21}$ problematic relations among the Malay, Chinese and Indian ethnic groups, increasing socio-political internalization of a radicalizing Islam, tight control of public opinion through the employment of the Internal Security Act (ISA) and tensions between the federal and (especially opposition-run) state governments, ${ }^{22}$ just to mention some of the findings such an analysis would reveal.

By combining the key findings from the OLI/RBV and institutional analysis, foreign investors get quite a deep insight into how the Malaysian market and society function respectively as well as how the two societal sectors relate to each other. As a consequence of these analyses foreign investors might adopt a 'wait and see' approach to investment in the Malaysian market due to the insecurities delineated in the societal sectors even though the key economic figures shows a positive tendency. After all, seen from foreign investors' perspective, their main point if they are to invest in the Malaysian market is to be reasonably sure of a positive return on their investment.

Arguably, a triangulation of the global and the national economy combined with an analysis of the societal context in which both the global and national economy are embedded constitutes a powerful tool to analyze 
the constitution of, in this case, a 'hilly' and dynamic socio-economic landscape. Due to the findings from the institutional analysis of the Malaysian society, an observer is prompted to ask, who are the main beneficiaries of the NEM economic policy: international investors or the national/local entrepreneurs? If one takes another look at Table 1, where the NEM approach to national economic development is outlined, the 'new' economic approach compared to the 'old' one relates to an almost neo-liberal policy. Gone is the 'nursing state', and in comes (global) open market forces that, besides introducing a 'minimal state', also have a fragmenting effect on the Malaysian/Penang market, thus increasing the competitive level there. Knowing, for example, that the Penang state government focuses very much on attracting FDI to finance its development schemes, this leaves out, for example, those SMEs that are not capable of attracting FDI or contribute to it by becoming either sub-contractors or suppliers to MNCs. ${ }^{23}$ The development of socio-economic fault-lines within the local SME community is thus a likely outcome of such a developmental scheme, thus creating the elements for a non-coherent domestic market that constitutes an easy target for predatory international business interests. From this perspective, the NEM and the various economic initiatives it represents do not lift the Malaysian economy out of the 'middle income trap' in which it currently finds itself, nor does it help domestic businesses move up the value chain. From the look of it, the NEM seems to be designed as a tool to attract more FDI, as this constitutes the principal source for (re-)fuelling further domestic economic developments. Basically, if Malaysia is to avoid losing its current status as a fast developing 'hill' in an otherwise dynamic 'hilly' Southeast Asian economic landscape, then it has to start addressing the social and political problems in the informal sector as highlighted in the institutional analysis. Potential global investors might not like what they find there!

\section{Conclusion}

This article has highlighted the explanatory power of a triangular approach in identifying the global economic impact on a national economic development scheme that is designed to ease socio-political tensions within the Malaysian society thus luring foreign investors to Malaysia. This holistic theoretical approach stands in sharp contrast to a decoupling approach that maintains that an analysis of just one of the three points in a given triangle is academically feasible thus disconnecting the relationship to the other points in the process. The strength of the 
triangular approach lies exactly in its ability to pinpoint the interdependencies among all three points in the model thus stressing the dynamic and holistic aspect among them.

This insight would be rather difficult to detect if an observer had taken a decoupling approach. From the perspective of an advocate of decoupling, government policy initiatives in relation to governing interethnic relations and their ramifications on the stability of the industrial setup would be perceived as belonging to the domestic sphere, thereby detaching it from a global context. As a consequence, the more subtle global inroads into the national economic setup in the form of domestic structural economic reforms would most likely have gone unnoticed due to the focus on domestic politicking.

As stated in the beginning of this article, it seems problematic in an age of globalization to talk about national political and economic decoupling from the global community. As discussed in this article it is impossible to decouple from a world that is characterized by increasing integration, interdependency and harmonization, keywords that bind the various societal, national and supra-national levels together. Based on the findings presented here, we have to realize that Harvey's notion of a time-space compression is correct when defining the current state of the global community, but this does not mean that the world has become more flat. On the contrary, its 'spiky' nature has become even more pronounced.

Michael Jakobsen is an associate professor at the Asia Research Centre (ARC) at Copenhagen Business School. His research interests include political and economic relations between China and Southeast Asia, ethnic Chinese business strategies and networking in Southeast Asia, ethnic identity, nationalism and economic and political globalization, human rights and Asian values and issues of security and processes of democracy.

\section{NOTES}

1 This paper was presented at the Fourth East Asian Net Research Workshop at Charles University, Prague, 6-7 October 2010.

2 See http://www.weforum.org/.

3 For more details, see Frank and Gills (1996).

4 For a more detailed discussion in this connection, see Gesteland (2005) and Nisbett et al. (2001).

5 Conrad de Aenlle, 'Decoupling: Theory vs. Reality', The New York Times, 7 February 2008.

6 Conrad de Aenlle, 'Decoupling: Theory vs. Reality', The New York Times, 7 February 
2008.

7 Harmonization and integration, pushed forward by the collapse of the Berlin Wall, Netscape, workflow software, outsourcing, offshoring, uploading, supply chaining, insourcing and in-forming.

8 Defined as wireless, voice over Internet, and file sharing.

9 Defined as the convergence of the ten 'flatteners', horizontalization of business practices, and economic liberalization of emerging markets.

10 For a more detailed discussion of the role of institutions in various types of markets, see North (1991).

11 For a full discussion of LMEs and CMEs, see Stephenson 2002.

12 For further readings on varieties of capitalism, see Whitley (1998) and Hall and Soskice (2001).

13 For a further discussion of the notion of trust, see Fukuyama (1995).

14 For a pertinent case study in this connection see 'Realities of Emerging Markets: Some Lessons from Unilever's Strategy for Lifebuoy \& Sunsilk in India', http://www. icmrindia.org/casestudies/catalogue/Marketing1/MKTA008.htm.

15 See http://country.eiu.com/Malaysia.

16 See https:// members.weforum.org/pdf/GCR09/GCR20092010fullreport.pdf.

17 The other three pillars are: 1Malaysia, the Governmental Transformation Programme (GTP), and the 10th Malaysian Plan 2011-2015.

18 See http://www3.weforum.org/docs/WEF_GlobalCompetitivenessReport_201011.pdf.

19 Basic requirements: institutions, infrastructure, macroeconomic environment and health and primary education.

20 Efficient enhancers: higher education and training, goods market efficiency, labour market efficiency, financial market development, technological readiness and market size.

21 Toh Kin Woon in Penang Economic Monthly, August 2010, pp. 16-19.

22 Francis Hutchinson in Penang Economic Monthly, July 2010, pp. 8-14.

23 According to Chin Yee Whah (2011 (forthcoming)),SMEs constitute about 99 per cent of the industrial setup in Penang.

\section{REFERENCES}

Ahlstrom, David and Garry D. Bruton 2010. 'International Market Entry', Chapter 6 in International Management. Strategy and Culture in the Emerging World. Cengage Learning.

Amir, Samir 1974, Accumulation on a World Scale, Vol. 1. New York: Monthly Review Press.

Ariffin, Norlela 2011. 'Innovating up to Speed'. Penang Economic Monthly, 5(May): 8-16.

Banaji, Jairus 1977. 'Modes of Production in a Materialist Conception of History'. Capital $\mathcal{E}$ Class, 3: 1-44.

Barney, J.B. 1991. 'Firm Resources and Sustained Competitive Advantage'. Journal of Management; 17(1): 99-120.

Beh Loo See 2007. 'Malaysian Chinese Capitalism: Mapping the Bargain of a Developmental State', in Malaysian Chinese and Nation Building. Before Merdeka and Fifty Years After, edited by Voon Phin Keong, 223-267. Kuala Lumpur: Centre for Malaysian Chinese Studies.

Campbell, L.B. 2005. 'The Political Economy of Environmental Regionalism in Asia', in 
Remapping East Asia. The Construction of a Region, edited T.J. Pempel, 216-235. Ithaca: Cornell University Press.

Chin, Yee Whah 2011. 'The Future of Small and Medium Sized Enterprises in Malaysia: Constraints and Opportunities' (forthcoming). The Journal of Asia-Pacific Business.

Dunning, J.H. and S. Lundan 2009. Multinational Enterprises and the Global Economy. 2nd ed. Cheltenham: Elgar.

Emmanuel, Arghiri 1972. Unequal Exchange. New York: Monthly Review Press.

Evans, P. 2005. 'Between regionalism and regionalisation: Policy Networks and the Nascent East Asian Institutional Identity', in Remapping East Asia. The Construction of a Region, edited by T.J. Pempel, 195-251. Ithaca: Cornell University Press.

Florida, Richard 2005. 'The World is Spiky'. The Atlantic Monthly. October: 48-51.

Frank, André Gunder 1978. Dependent Accumulation and Underdevelopment. London: The Macmillan Press.

Frank, André Gunder and Barry K. Gills 1996. A Structural Theory of the Five Thousand Year World System. Available from: http://www.rrojasdatabank.info/agfrank/ structural.html.

Friedman, Thomas L. 2005. The World is Flat: A Brief History of the Twenty-First Century. New York: Farrar, Straus and Giroux.

Fukuyama, Francis 1995. Trust. The Social Virtues and the Creation of Prosperity. London: Penguin.

Gesteland, Richard R. 2005. Cross-Cultural Business Behavior. Negotiating, Selling, Sourcing and Managing Across Cultures. 4th ed. Copenhagen: Copenhagen Business School Press.

Hall, Peter A. and David W. Soskice 2001. Varieties of capitalism: the institutional foundations of comparative advantage. Oxford: Oxford University Press.

Harvey, David 1989. The Condition of Postmodernity: An Enquiry into the Origins of Cultural Change. Oxford and Cambridge, MA: Blackwell.

Hutchinson, Francis 2009. Developmental States and Economic Growth at the Sub-National Level: The Case of Penang. Singapore: Institute of Southeast Asian Studies.

Jacobsen, Michael and Ole Bruun 2000. Human Rights and Asian Values: Contesting National Identities and Cultural Representations in Asia. Richmond: Curzon Press.

Krugman, Paul R. and Maurice Obstfeld 2009. International Economics. Theory and Policy. 8th ed. Boston: Peason Addison-Wesley.

Nesadureai, H.E.S. 2004. 'Attempting developmental regionalism through AFTA: the domestic sources of regional governance', in Governing the Asia Pacific, edited by K. Jayasuriya, 37-55. London: Palgrave.

Nisbett, Richard E., Kaiping Peng, Incheol Choi and Ara Norenzayan 2001. 'Culture and Systems of Thought: Holistic Versus Analytic Cognition'. Psychological Review, 108(2): 291-310.

North, Douglass C. 1991. 'Institutions'. The Journal of Economic Perspectives, 5(1): 97112.

Penang Development News 2003. 'Penang's Industrialisation Journey', 1-24.

Peng, Mike W. 2009. 'Leveraging Capabilities Globally', Chapter 4 in Global Business, South-Western Cengage Learning.

Peng, Mike W. 2002. 'Towards an Institution-Based View of Business Strategy'. Asia Pacific Journal of Management, 19: 251-267.

Peng, Mike W. and Klaus Meyer 2011. 'Starting International Business', Chapter 11 in International Business. South-Western Cengage Learning.

Peng, Mike W. and J. Zhou 2005. 'How Network Strategies and Institutional Transitions Evolve in Asia'. Asia Pacific Journal of Management, 22: 321-336.

Poh, Heem Heem 2010. 'The New Economic Model - Strategic Policy Directions'. Penang 
Economic Monthly, (June): 46-49.

Porter, M.E. 1990. 'The Competitive Advantage of Nations'. Harvard Business Review, March-April: 73-93.

Rugman, A.M. and A. Verbeke 2004. 'A Perspective on the Regional and Global Strategies of Multinational Enterprise'. Journal of International Business Studies, 35: 3-18.

Scott, W.R. 2008. 'Institutions and Organisations: Ideas and Interests'. 3rd ed. Thousand Oaks, CA: Sage.

Shenkar, O. 2004. 'One More Time: International Business in a Global Economy'. Journal of International Business Studies, 35: 161-171.

Stephenson, Laura B. 2002. 'The Social Democratic Program in LMEs: A Study of Welfare Policy Variation in the Anglo-American Democracies'. Prepared for presentation at the Annual Meeting of the Midwest Political Science Association, Chicago IL, 25-28 April 2002.

Stiglitz, Joseph E. 2006. Making Globalization Work. New York: W.W. Norton and Company.

Wallerstein, Immanuel 1979. The Capitalist World-Economy. Cambridge: Cambridge University Press.

Whitley, R. 1998. 'Internationalization and Varieties of Capitalism: The Limited Effects of Cross-national Coordination of Economics Activities on the Nature of Business Systems'. Review of International Political Economy, 5(3): 445-481.

Yeah, Tricia 2011. 'Reversing the Brain Drain Requires a Paradigm Shift'. Penang Economic Monthly, (June): 40-42. 